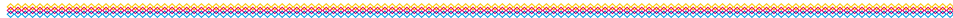

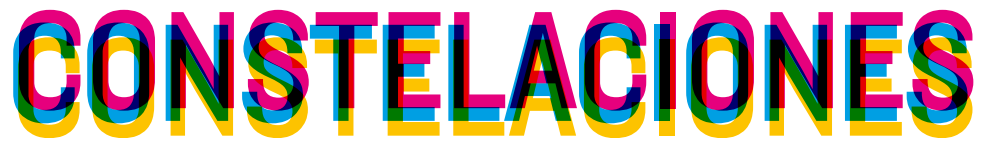

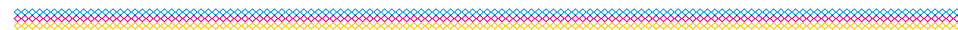




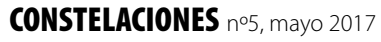

Revista de Arquitectura de la Universidad CEU San Pablo

Architecture Magazine of CEU San Pablo University

Periodicidad anual

Annual periodicity

COMITÉ DE REDACCIÓN EDITORIAL COMMITTEE

\section{Dirección Directors}

Juan García Millán

Santiago de Molina

Jefa de Redacción Editor in Chief

Covadonga Lorenzo Cueva

Secretario de Redacción Editorial Clerk

Rodrigo Núñez Carrasco

Maquetación y producción Design and production

María Fernández Hernández

Clara Martínez-Conde Rubio

Revisión de textos en inglés English Editing

Carlota Sáenz de Tejada Granados

Responsable Web Web Page Manager

María Isabel Castilla Heredia

Diseño Original Original Design

Juan Roldán Martín

\section{Vocales Board Members}

María Dolores Gómez Pulido. Escuela Politécnica Superior, Universidad CEU San Pablo, Madrid

Rocío Carvajal Alcaide. Escuela Politécnica Superior, Universidad CEU San Pablo, Madrid

Clara Eugenia Maestre Galindo. Escuela Politécnica Superior, Universidad CEU San Pablo, Madrid

\section{CONSEJO EDITORIAL EDITORIAL BOARD}

Beatriz Colomina. School of Architecture, Princeton University, New Jersey

Carmen Díez Medina. Escuela de Ingeniería y Arquitectura, Universidad de Zaragoza

María Antonia Frías Sargadoy. Escuela Técnica Superior de Arquitectura, Universidad de Navarra

Juan Miguel Hernández Léon. Escuela Técnica Superior de Arquitectura, Universidad Politécnica de Madrid

Juan José Lahuerta Alsina. Escuela Técnica Superior de Arquitectura, Universidad Politécnica de Cataluña, Barcelona

Eduardo Leira Sánchez. Ex director del Plan General de Ordenación Urbana, Madrid

Joaquín Medina Wamburg. Facultad de Aquitectura Diseño y Urbanismo, Universidad de Buenos Aires

Zaida Muxí Martínez. Escuela Técnica Superior de Arquitectura, Universidad Politécnica de Cataluña, Barcelona José Joaquín Parra Bañón. Escuela Técnica Superior de Arquitectura, Universidad de Sevilla

Víctor Pérez Escolano. Escuela Técnica Superior de Arquitectura, Universidad de Sevilla

Fernando Pérez Oyarzún. Escuela de Arquitectura y Diseño, Pontificia Universidad Católica, Santiago de Chile Judith Sheine. School of Architecture and Allied Arts, University of Oregon, Portland

Andrés Walliser Martínez. Global Design, New York University, Nueva York

\section{ISSN 2340-177X}

Depósito legal M-13872-2013

(c) de los textos, sus autores

(c) de las imágenes autorizadas

(C) Revista Constelaciones

๑) Escuela Politécnica Superior, Universidad CEU San Pablo

Universidad CEU San Pablo

Escuela Politécnica Superior

Urbanización Montepríncipe, s/n

Alcorcón, 28925. Madrid (España)

constelaciones@eps.ceu.es

www.uspceu.es

www.revistaconstelaciones.wordpress.com

Edición Edition

Fundación Universitaria San Pablo CEU

Madrid, España

Impresión Printing

VA Impresores

Impreso en España Printed in Spain

Distribución Distribution

CEU Ediciones

\author{
INDEXACIÓN INDEXING \\ Índices Index \\ Latindex \\ Avery Index \\ ErihPlus \\ MIAR
}

Bases de datos Data bases

Dialnet

Índices en evaluación Evaluation Index

Web of Science

Scopus

Dulcinea

EBSCO

Sherpa Romeo
Los textos que componen Constelaciones se obtienen mediante convocatoria pública. Para que los trabajos recibidos entren en el proceso de selección de los artículos a publicar deben ser trabajos originales no publicados anteriormene, con una extensión recomendada de 3.000 palabras, título, resumen (un máximo de 150 palabras) y palabras clave (un mínimo de cuatro palabras), en español y en inglés. Tras haber cumplido estos requisitos (y los correspondientes incluidos en las normas editoriales de la revista, disponibles para consulta en formato digital desde el comienzo de la convocatoria), tiene lugar un proceso de revisión y evaluación de los artículos previa aceptación de los mismos para su publicación. Para acometer dicho proceso, y con el fin de asegurar la calidad de los contenidos, la revista Constelaciones recurre a evaluadores externos a la institución editora y anónimos (cada artículo es evaluado por dos de ellos) encargados de someter a crítica los mismos. Todos los artículos de investigación publicados en esta revista han pasado por dicho proceso. La recepción de artículos se extendió hasta el 30 de septiembre de 2016. Texts included in Constelaciones are obtained by public announcement. Only original papers that have not been previously published will be included in the process of selection of articles. They should not exceed 3.000 words and should include a title, an abstract (no more than 150 words) and keywords (a minimum of four words), in Spanish and English. After having fulfilled these requirements (and those included in magazine editorial standards, available for consultation from the beginning of the Call for Papers), occurs a process of review and evaluation of articles upon acceptance of them for publication. To undertake this process, and in order to ensure the quality of the contents, Constelaciones turns to external and anonymous evaluators to the institution (each article is evaluated by two of them) responsible for the critic. All the articles published in this journal have undergone this process. The deadline for reception was extended until September 30, 2015.

Todos los derechos reservados. Esta publicación no puede ser reproducida, ni en todo ni en parte, ni registrada, ni transmitida, ni almacenada en ninguna forma ni por ningún medio, sin la autorización previa y por escrito del equipo editorial. En este número se han utilizado algunas imágenes de las que no se ha podido identificar al propietario de los derechos. En estos casos hemos entendido que las imágenes son de libre uso. En caso de identificar alguna de estas imágenes como propia, por favor, póngase en contacto con la redacción de Constelaciones. Los criterios expuestos en los diversos artículos de la revista son responsabilidad exclusiva de sus autores y no reflejan necesariamente los que pueda tener el equipo editoral. El equipo editorial de la revista no se responsabiliza de devolver la información enviada a la redacción a no ser que se le solicite expresamente. All rights reserved. This publication cannot be reproduced, in whole or in part, nor registered, transmitted or stored in any form or by any means, without the written permission of the Editorial team. In this issue some images were used without knowing the owner of the rights. In these cases, we have understood that the images are free of use. In case you identify written permission of the Editorial team. In this issue some images were used without knowing the owner of the rights. In these cases, we have understood that the images are free of use. In case you identify
any of these images as your own, please, contact with the Editorial staff of Constelaciones. The opinions expressed in this issues's articles are entirely the responsibility of their authors and are not necessarily shared by the editors of this journal. The publisher don't take responsibility for returning submitted material which is not expressly requested. 

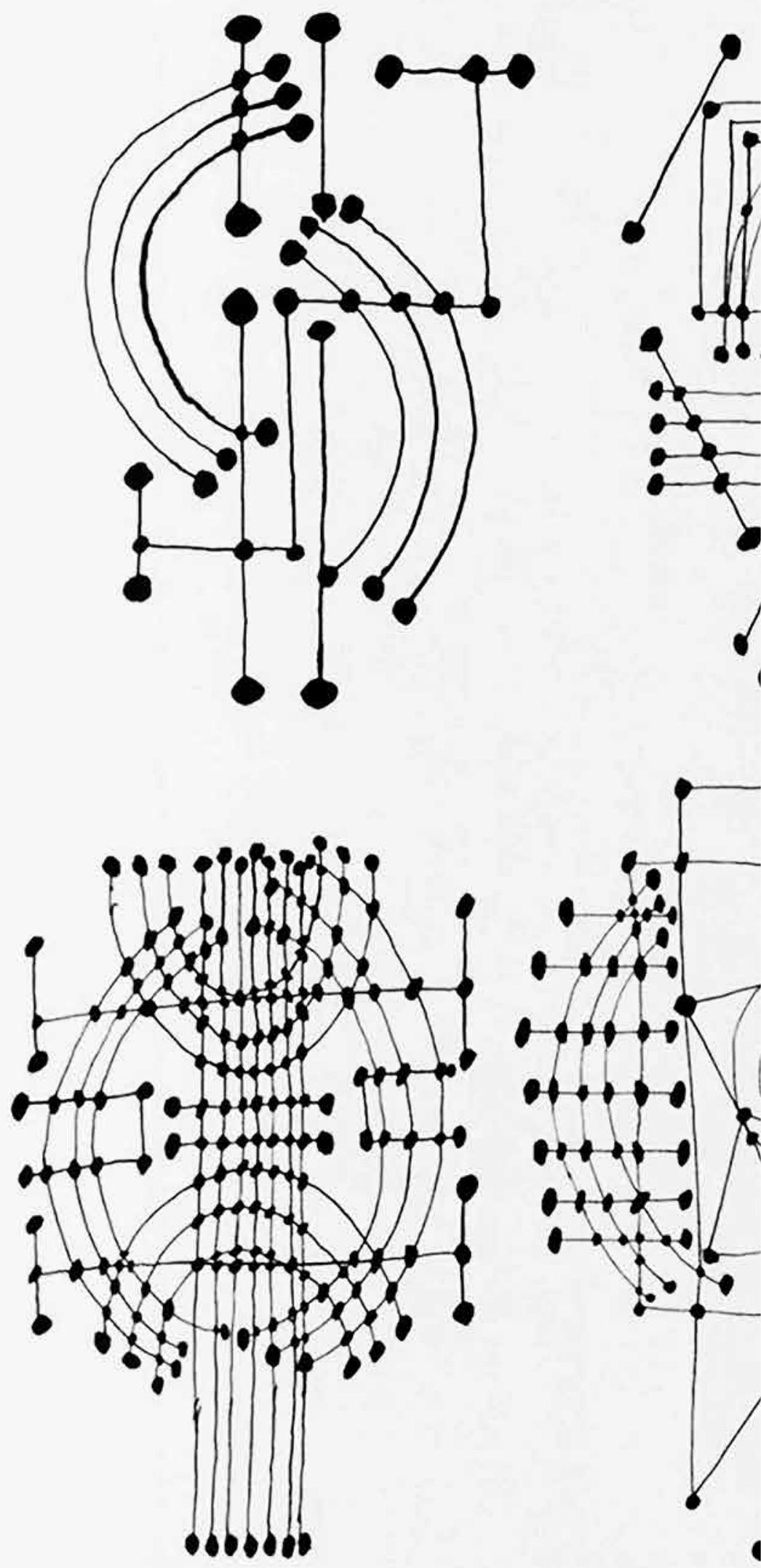


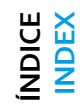

จ

ก)

品

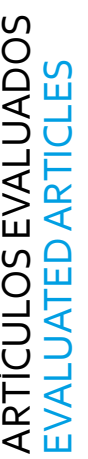

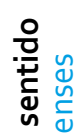

बํำ

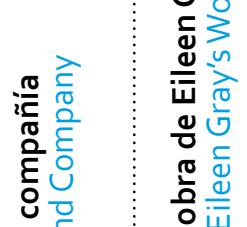

드.

ฮั

茄

:

ที่ ปั อ

苦云

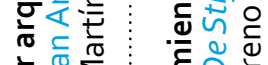

过

ह $\frac{2}{3}$

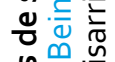

눈

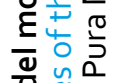

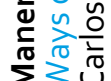

นับ

음

๗ั

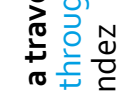

号

궁워

뜬

원

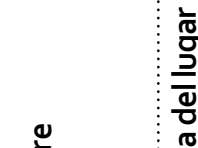

임

ส

응

离

$: \frac{\mathscr{2}}{ \pm}$

을

tั

ग

ํํำ

ํㅡㄹ

:

응 $\frac{\cup}{0}$

บับ

인

든

冚

号京

ब

ฮั

을

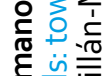

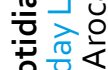

언

으 $\frac{\pi}{\pi}$

产

등 똥

告崖

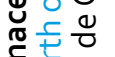

ํํㄴ

일

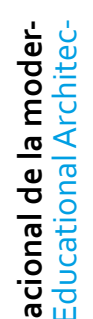

高
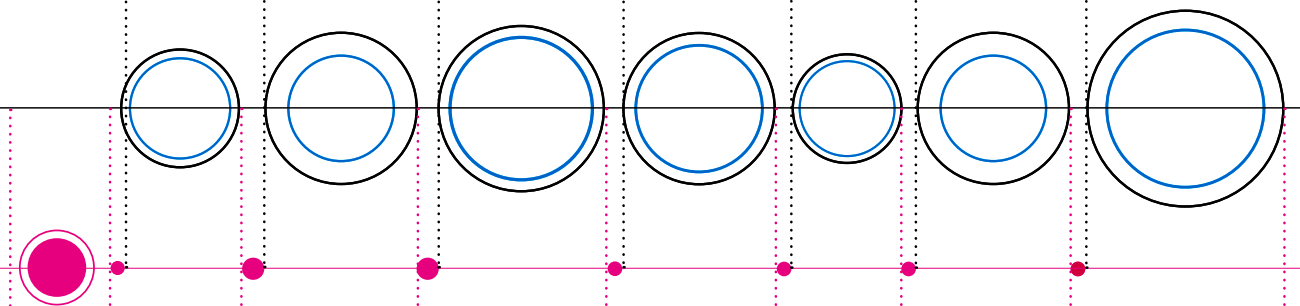

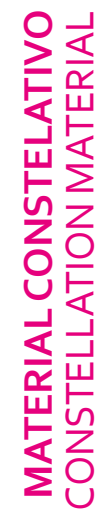

岂㟧

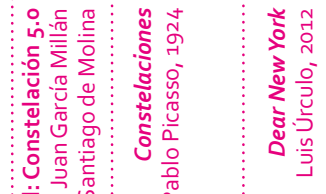

$=\quad \stackrel{m}{\sim}$

$\stackrel{\bullet}{v}$
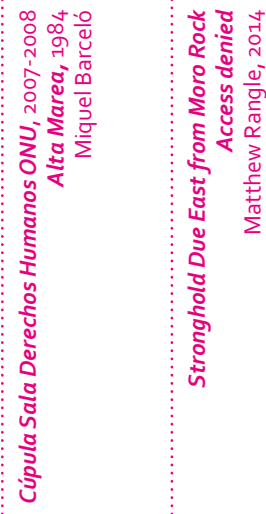

$\overline{6}: \AA$

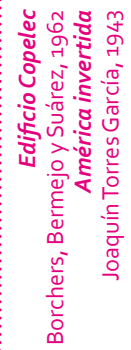

$\infty$

응 


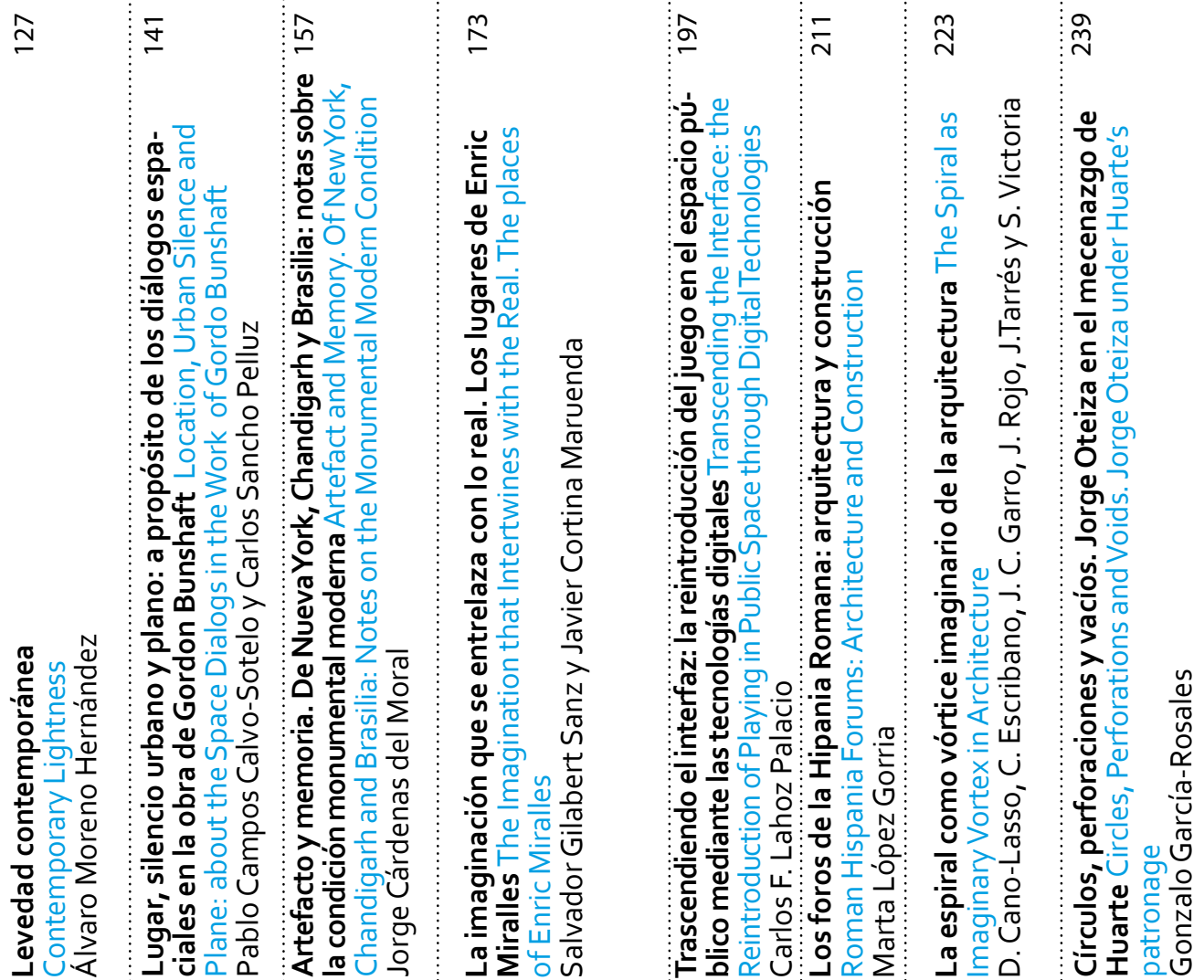
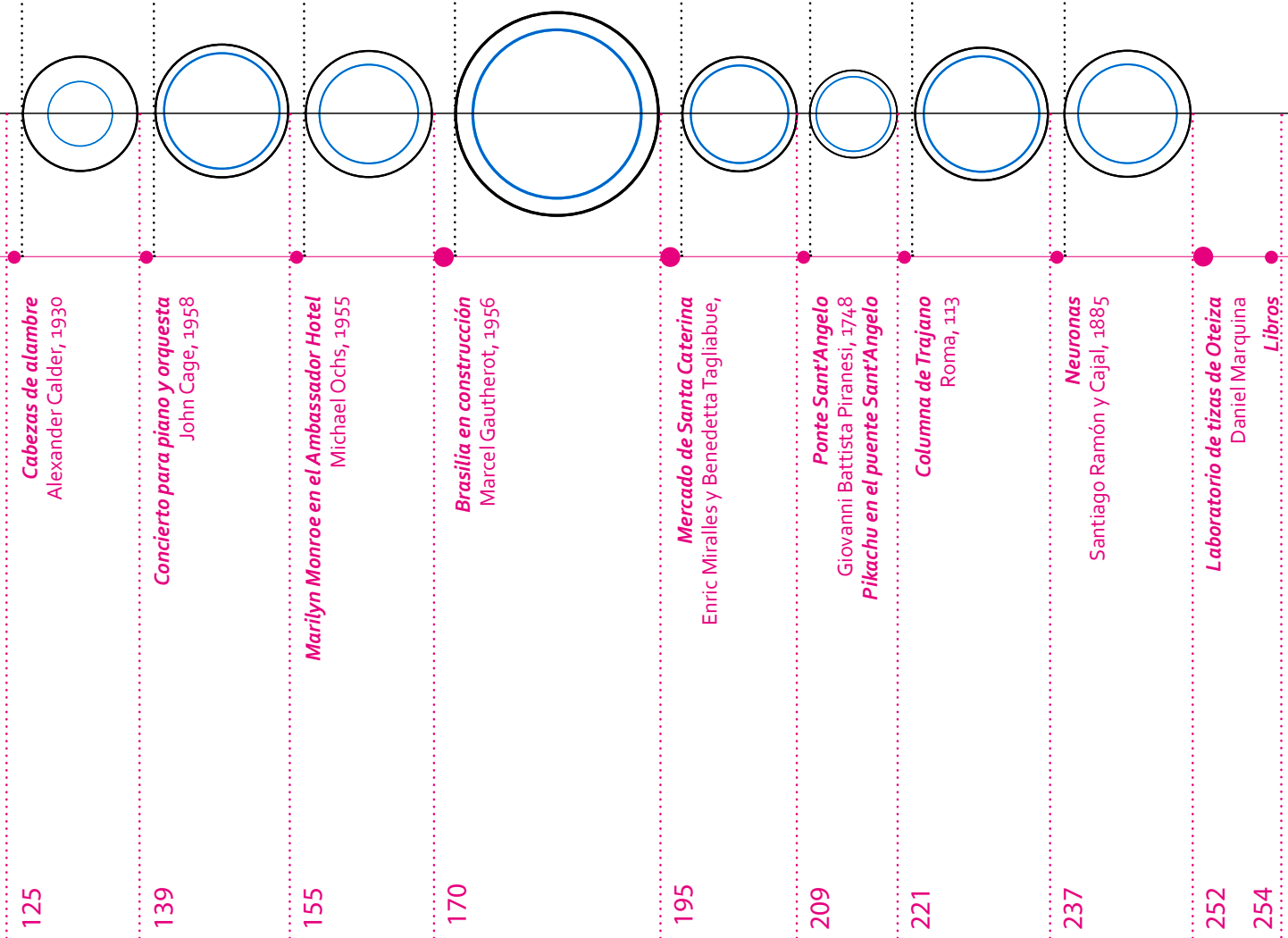


\title{
Ecos del movimiento De Stijl en la obra de Eileen Gray
}

\section{Echoes of the De Stijl Movement}

in Eileen Gray's Work

\author{
María Pura Moreno Moreno \\ Arquitectura y Tecnología de la Edificación, Universidad Politécnica, Cartagena \\ Traducción Translation Pedro Monreal Mármol
}

\section{Palabras clave Keywords}

De Stijl, Eileen Gray, sinergia, mobiliario, arquitectura

De Stijl, Eileen Gray, synergy, furniture, architecture

\section{Resumen}

Este artículo expone la influencia del Movimiento De Stijl en la obra de Eileen Gray gracias al hallazgo de interconexiones temporales en publicaciones y exposiciones, pero sobre todo al análisis sintético de los proyectos y su confrontación. El aprendizaje autodidacta de Eileen Gray se fundamentó tanto en la observación crítica al arte y la arquitectura de su contexto, como en sus propias inquietudes y destrezas. El vínculo de su producción con los movimientos de vanguardia holandeses se remonta a sus inicios como diseñadora cuando, por ejemplo, su instalación Boudoir de Monte-Carlo, situada en el Salon des Artistes Décoráteurs de París (1923) tuvo eco en la revista de difusión de la Escuela de Amsterdam, Wendingen (1924).

Los postulados del grupo De Stijl asumieron la revolución visual del Cubismo vinculada a la concepción espacial, y su repercusión inmediata en proyectos de arquitectura y diseño fue generalizada en la obra de autores observadores como Eileen Gray.

\section{Abstract}

This article exposes the influence of the De Stijl movement in Eileen Gray's work being based on the finding of temporary interconnections on publications and exhibitions, but especially on the the synthetic analysis of the projects and works and their confrontation. Eileen Gray's self-taught learning was based on both, the critical remark to the art and architecture of her context and in her own interests and skills. The link between her work and the Dutch avant-garde movements goes back to her beginnings as a designer when, for example, her installation Boudoir for Monte-Carlo, placed in the Salon des Artistes Décoráteurs in Paris (1923) had an important impact in the magazine of the Amsterdam's School, Wendingen (1924).

De Stijl Group's postulates assumed the visual revolution of cubism, linked to the spatial conception, and its immediate repercussion in projects of architecture and design was widespread in the work of observers authors such as Eileen Gray. 
La obra de Eileen Gray refleja la influencia de la vanguardia contemporánea. Su aprendizaje arquitectónico estuvo precedido tanto de la práctica de otras técnicas -pintura, laca, mobiliario, tejido de tapices- como del conocimiento de discursos y proyectos de su tiempo. El análisis de su enseñanza autodidacta engloba la convergencia de dos curvaturas: (1) una interna y otra externa. La primera, más subjetiva, comprende su cartografía cognoscitiva previa a la práctica, en relación al propio deseo e imaginación de la autora. La segunda, objetiva y contextual, abarca su conocimiento, tanto de los proyectos de otros autores como de las críticas que éstos suscitaron en el pensamiento y el debate profesional. En este segundo ámbito intervienen las ideas generadas por los protagonistas de diversos movimientos artísticos y arquitectónicos.

Cruce de Miradas: De Stijl-Eileen Gray. El recorrido por acontecimientos artísticos de la Europa de entreguerras permite establecer conexiones que demuestran la confluencia entre el aprendizaje experimental de Eileen Gray y las reivindicaciones del grupo De Stijl. La atención cruzada entre su obra y la de artistas holandeses aparece desde sus primeras exposiciones de objetos.

Eileen Gray inauguró en 1922 la Galería Jean Desert, dedicada a la decoración de apartamentos y a la producción de lacados, muebles y tapices. (2) El objetivo al mostrar al público sus diseños, junto al de artistas elegidos, perseguía introducirlos en el debate artístico. Con ese fin expuso por primera vez, en el Salon d'Automne de París de 1922, un paravent, una cómoda y un tapiz. En aquella muestra sus objetos compartían espacio expositivo con proyectos arquitectónicos como la Maison Citröhan y la Ville Contemporaine pour Trois Millions d'Habitants de Le Corbusier o el Pavillon de l'AéroClub de Robert Mallet-Stevens. En diciembre de 1922, como consecuencia del éxito y el interés suscitado por sus piezas, algunas de ellas fueron elegidas para formar parte del envío oficial de obras francesas a la exposición colectiva Arte y mobiliario en Ámsterdam, entrando allí en contacto con el arquitecto holandés (3) Jan Wils. (Fig. 1)

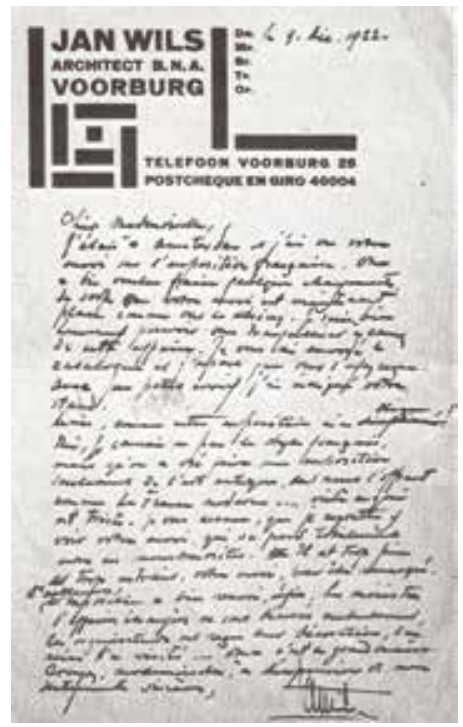

Fig. 1. Wils, Jan: Carta a Eileen Gray, 9 de diciembre de 1922. Archive of Art and Design, Victoria \& Albert Museum (ADD/9/162-1980).

Eileen Gray's work reflects the influence of contemporary avant-garde. Her architectural learning was preceded by both, the practice of other techniques - painting, lacquer, furniture and woven tapestries-, as well as knowledge gained by attending speeches and observing projects that were within her reach in this context at the time. The analysis of her selftaught learning encompasses the convergence of two curvatures, (1) one internal and other external. The first one, which was more subjective, is a type of cognitive mapping of what the author desired as well as her own imagination taking hold, while the second one, which is objective and contextual, takes in her knowledge of both the projects of other authors and the critiques that these provoked in ways of thinking and professional debates. In the latter, the ideas generated by the protagonists of different artistic and architectural movements, also play a part.

An exchange of glances: De Stijl- Eileen Gray. The path that artistic events of the interwar period in Europe followed, allow for connections that demonstrate the confluence between Eileen Gray's experimental learning and the claims of De Stijl's Group to be later established. The criss cross connections between her work and Dutch artists' work is obvious from her first exhibitions of objects.

Eileen Gray inaugurated the Gallery of Art Jean Deser, in 1922, whose theme was the decoration of apartments and the production of lacquers, furniture and tapestries. (2) The aim of showing her designs to the public, together with other works of co-artists, was to make them known in artistic circles; with this in mind, she puts a paravent, a commode and a tapestry on show, for the first time in the Salon d'Automne of Paris in 1922. In the exhibition, her objects stood side by side 
En el XIV Salon des Artistes Décoráteurs de París de 1923, Gray realizó la instalación denominada Boudoir de Monte-Carlo, (4) exponiendo un conjunto de muebles cuya disposición invitaba a un uso doméstico diferente. Aquel espacio suscitó numerosas críticas entre la prensa francesa; (5) sin embargo, fue bien acogido por el sector profesional más progresista de París y sobre todo por el entorno vanguardista holandés. El arquitecto holandés Albert Boeken, trasladado a París para conocer las novedades del Salon d'Automne, elogió en la revista Bouwkunding Weekblad el carácter innovador de la propuesta de Eileen Gray, subrayando la pureza de líneas de las piezas y el tratamiento conceptual del conjunto. En aquella misma publicación, Sybold van Ravesteyn reseñó aquel Boudoir, (Fig. 2) destacando la geométrica abstracción de sus muebles. El efecto novedoso del conjunto provocó que el arquitecto Jacobus Johannes Pieter Oud dirigiera una misiva (Fig. 3) a Eileen Gray tratando de averiguar si ella era la abanderada de algún movimiento emergente hasta entonces desconocido. (6)

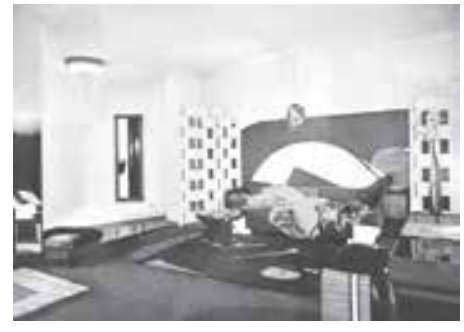

Fig. 2. Gray, Eileen: Instalación Boudoir de Monte-Carlo en el xIV Salon des Artistes Décoráteurs de París en 1923. Revista Wendingen, 1924.

Fig. 3. Oud, J.J.P.: Postal remitida a Eileen Gray, 31 Agosto de 1931. Archive of Art and Design, Victoria \& Albert Museum (ADD/9/163-1980).

A raíz de aquel descubrimiento, la revista holandesa Wendingen (7) dedicó un número completo al trabajo de Eileen Gray, (Fig. 4) mostrando fotografías del Boudoir y también de un apartamento diseñado entre 1918 y 1922 para madame Mathieu Lévy, en la rue de Lota de París. Las imágenes de aquellos
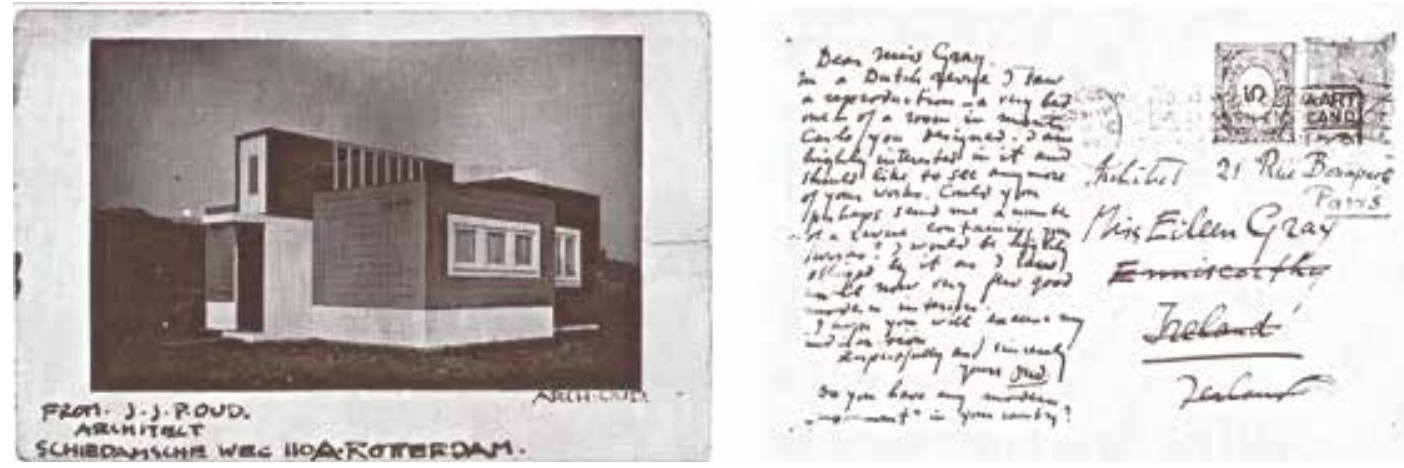

with architectural projects such as the Maison Citrohan and the Ville Contemporaine pour Trois Millions d'Habitants by Le Corbusier or the Pavillon de l'Aero-Club by Robert Mallet-Stevens. In December of 1922, as a result of the success and the interest aroused by her pieces of art, some of them were chosen to form part of the official package of French works sent to take part in the collective exhibition Art and Furniture in Amsterdam, where contact was made with the Dutch architect (3) Jan Wils. (Fig. 1)

In the XIV Salon des Artistes Décorateurs of Paris in 1923, Gray set up the exhibition called Boudoir of Monte-Carlo, (4) exhibiting an ensemble of furniture whose layout encouraged a different type of use for everyday areas of the home. The layout was quite criticized in the French press (5), although it was well received by the more progressive professional sector of Paris and especially by Dutch avant-garde circles. The Dutch architect Albert Boeken went to Paris to visit the Salon d'Automne, and praised, in the magazine Bouwkunding Weekblad, the innovative character of Eileen Gray's contribution, pointing out the purity of lines of the pieces used and the whole conceptual treatment. In the same magazine Sybold van Ravesteyn gave special mention to the very same Boudoir, (Fig. 2) and the geometric abstraction of its furniture. The innovative effect of the work exhibited was such that the architect Jacobus Johannes Pieter Oud sent a missive (Fig. 3) to Eileen Gray in an attempt to find out if she was the standard bearer of some new movement unknown till then. (6) 


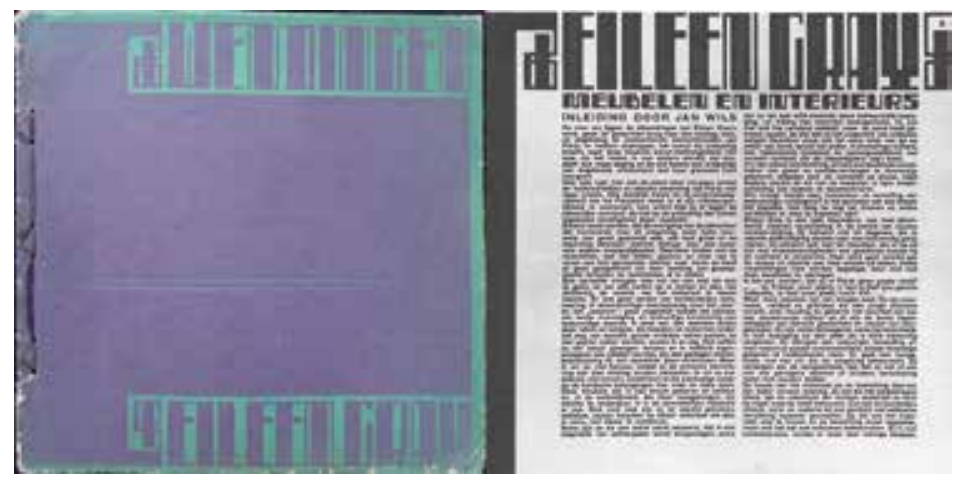

interiores se complementaban con dos artículos referidos a aquella singular obra: uno de Jan Wils, destacando el carácter emotivo de los muebles y otro del arquitecto crítico Jean Badovici, (8) donde afirmaba que en su opinión, aquellos originales diseños geométricos superaban el conflicto entre la idea y la forma material, pero sobre todo auguraban el tránsito inmediato de la diseñadora hacia la disciplina del proyecto arquitectónico.

La vanguardia holandesa en aquel momento estaba dividida (9) en dos sectores: los miembros de De Stijl (10) y los artistas involucrados en torno a la revista Wendingen. La diferencia entre la concepción del arte y la arquitectura de ambos grupos había sido descrita por Theo van Doesburg, (11) identificando a los integrantes del grupo Wendingen como artistas experimentales inspirados en el expresionismo alemán, frente a los precursores de De Stijl considerados como los auténticos constructores.

Si los trabajos iniciales de Eileen Gray habían sido descubiertos y admirados por los miembros de Wendingen, su comprensión espacial y arquitectónica estaría más influenciada por los conceptos enunciados por De Stijl referidos a la forma, la economía, la función, la luz o el tiempo.

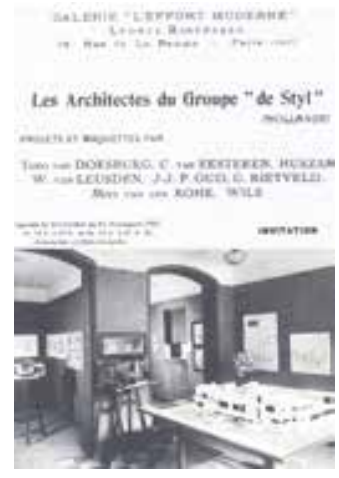

Fig. 4. Portada de la revista Wendingen dedicada a la obra de Eileen Gray, 1924.

Fig. 5. Invitación a Les architectes du groupe de Stijl de Hollande en la Galería L'Effort Moderne de París, del 15 de octubre al 15 de noviembre de 1923. Fotografía de la exposición.

1918-1922. The pictures of these interiors were accompanied by two articles that spoke of this unique project; one of the articles was that of Jan Wils, who placed particular emphasis on the emotional character of the furniture, and the other of the architect critic Jean Badovici, (8) who expressed that, in his opinion, the original geometric designs present allowed for the overcoming of the conflict between the idea and the material form, but above all they predicted the immediate transit of the designer to the discipline of the architectural project.

The Dutch avant-garde movement was divided (9) into two sectors: the members of De Stijl (10) and the artists involved in the magazine Wendingen. The difference between the conception of art and architecture in both groups had been described by Theo van Doesburg, (11) labeling the members of the Wendingen group as experimental artists inspired by German expressionism, while the members of De Stijl were considered to be the authentic constructors of the movement.

While it is true that the initial work of Eileen Gray had been discovered and admired by members of Wendingen, an understanding of the use of space and its architecture was more influenced by De Stijl, especially when it came to shape, economy, light or time.

The work of the De Stijl group made a great impression within French architectural circles thanks to the exhibition Les architectes du groupe De Stijl (Fig. 5) which took place in 1923 in the gallery L'Effort Moderne, Paris. (12) The gallery 
En ese marco temporal, el trabajo del grupo De Stijl obtuvo una gran repercusión en el ámbito arquitectónico francés gracias a la exposición Les architectes du groupe De Stijl, (Fig. 5) realizada en 1923 en la galería L'Effort Moderne de París. (12) El galerista Léonce Rosenberg había encargado previamente al grupo holandés el proyecto de una vivienda capaz de plasmar las ideas neoplasticistas en la disciplina arquitectónica. Aquel encargo original se diversificó en tres propuestas diferenciadas. La primera, la Maison Rosenberg, (Fig. 6) extendía las reglas compositivas de su interior de manera centrífuga al exterior. En la segunda, el Hôtel Particulier, (Fig. 7) se experimentaba con la multiplicación de esquinas disolviendo cualquier fachada principal en favor del conjunto. Y por último, en la Maison d'Artiste, (Fig. 8) el dinamismo volumétrico era acentuado por perspectivas con puntos de vista anti-gravitatorios. Las maquetas, pero sobre todo los dibujos expuestos ilustraban una complejidad alejada de las reglas compositivas tradicionales de proyectar. La ortodoxia de la bidimensionalidad había sido sustituida por el carácter de lo volumétrico, capaz de simultanear llenos y vacíos gracias a superficies planas independientes representadas en el grafismo de las denominadas contra-construcciones. (13)
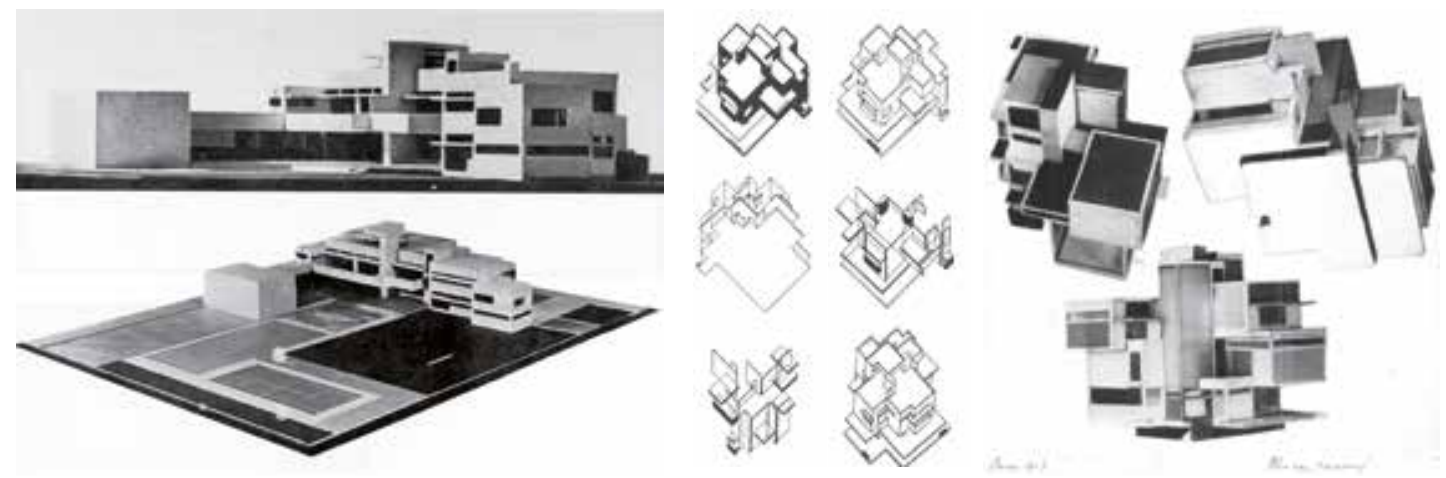

Fig. 6. Van Doesburg, Theo; Van Eesteren, Cornelis: Maqueta de la Maison Rosenberg, 1923. Fig. 7. Van Doesburg, Theo y Van Eesteren, Cornelis: Hôtel Particulier, 1920.

Fig. 8. Van Doesburg, Theo; Van Eesteren, Cornelis; Rietveld, Van Doesburg, Theo y Van Eesteren, Cornelis: Maison d'Artiste, 1922.

owner, Léonce Rosenberg, had previously commissioned the Dutch Group with the project of a home capable of capturing neoplastic ideas in architecture. The job was originally divided up into three different proposals: the first one was the Maison Rosenberg (Fig. 6) whereby the interior compositional rules could be seen to extend outside the home in a centrifugal way. In the second one, the Hôtel Particulier (Fig. 7) the increase in the number of corners meant there was no main façade and therefore, no area was more important than another, and the home was perceived as a 'whole' rather than one made up of individual parts, and finally, the Maison d 'Artiste (Fig. 8) where the volumetric dynamism was accentuated by perspectives with anti-gravitational views. The models and more drawings on display, were able to illustrate a complexity that moved away from the traditional compositional rules of projecting. The orthodoxy of the bi-dimensionality had been replaced by the volumetric form capable of simultaneous fullness and emptiness thanks to independent surfaces represented in the graphic form of the so-called Contra-Construction. (13)

The projects -and their graphic representation- put on show by the Dutch group in the exhibition had a liberating effect on Eileen Gray's work (14) and they had an immediate influence on her objects and in the spatial conception of her pending architectural projects.

Eileen Gray's knowledge of De Stijl postulates was increased thanks to the dissemination of texts by members of the group in the magazine L'Architecture Vivante, directed by Jean Badovici; 'L'Architecture Future Néo-Plasticienne', written by Piet Mondrian (15) and 'L'Evolution du l'Architecture Moderne in Hollande', by Theo van Doesburg (16) revealed the seven- 
Los proyectos y su representación gráfica mostrados por el grupo holandés en aquella exposición tuvieron un efecto liberador en la obra de Eileen Gray (14) e influyeron inmediatamente en sus objetos y en la concepción espacial de su inminente trabajo arquitectónico.

El conocimiento de Eileen Gray de los postulados de De Stijl se incrementó gracias a la divulgación de textos de miembros del grupo en la revista L'Architecture Vivante, dirigida por Jean Badovici, como por ejemplo, 'L'Architecture Future Néo-Plasticienne', firmado por Piet Mondrian (15) y 'L'Evolution du l'Architecture Moderne in Hollande' de Theo van Doesburg, (16) donde se exponían los diecisiete postulados de la nueva arquitectura neoplástica. Aquellos artículos aparecían en la publicación acompañados por las imágenes de los proyectos más significativos del grupo como Maison Schröder en Utrech, de G. Rietved; Maison d'Artiste y Hôtel Particulier, de Théo van Doesburg, C.van Eesteren y G. Rietvelt o las plantas de Maison Rosenberg con fotografías de su maqueta bajo el título Eurythmie des volumes et des plans.

Gracias a su relación personal con Jean Badovici, Eileen Gray fue testigo del descubrimiento de aquellos proyectos y tuvo ocasión de conocer personalmente a algunos de los miembros del grupo, como B. Bijvoet, Sybold van Ravesteyn, J.J.P. Oud y J.Wils. (17)

\section{De Stijl en los diseños de Eileen Gray}

LOS TAPICES. Eileen Gray experimentó con la pintura durante toda su vida y gracias a las influencias de la Bauhaus y del movimiento De Stijl, su obra pictórica transitó desde lo figurativo hasta la abstracción.

En 1909, junto a su amiga Evelyn Wyld, Eileen Gray viajó al Atlas marroquí y aprendió la técnica del tejido y el teñido de la lana. Los bocetos de sus tapices eran realizados en gouache sobre papel milimetrado y sus composiciones evolucionaron en paralelo a sus intereses artísticos; si al principio
Fig. 9. Gray, Eileen: Tapiz,1925

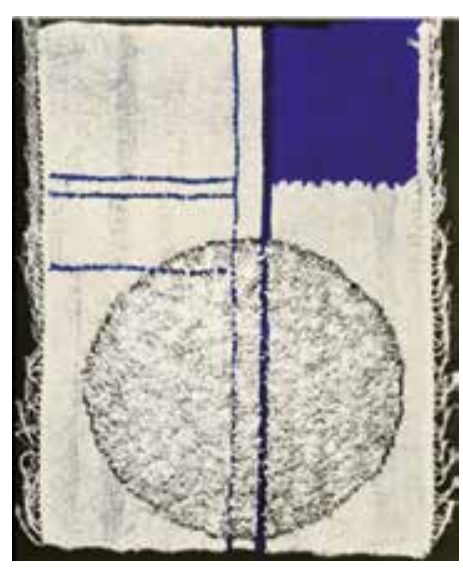

teen principles of neoplastic architecture. These articles appeared in the magazine accompanied by pictures of the most significant projects of the group such as Maison Schröder in Utrecht by G. Rietved, Maison d'artiste and Hôtel Particulier by Théo van Doesburg, C.van Eesteren and G. Rietvelt or the Maison Rosenberg with photographs of his models, titled Eurythmie des volumes et des plans.

Thanks to her personal relationship with Jean Badovici, Eileen Gray witnessed the discovery of these projects and had the opportunity to meet personally some of the members of the group, such as B. van Ravesteyn Bijvoet, Sybold, J.J.P. Oud and J.Wils. (17)

\section{De Stijl in Eileen Gray's designs.}

TAPESTRIES. Eileen Gray experimented with painting throughout her life, going from figurative painting right through to the abstract, influenced by the Bauhaus and De Stijl movements.

In 1909, together with her friend Evelyn Wyld, she travelled to the Moroccan Atlas and learned fabric and wool dyeing techniques. She did her tapestry sketches in gouache on graph paper and they evolved on a par with her artistic interests; if initially they were flowing and complicated, later they were simplified by the introduction of black orthogonal lines of different widths that delimited surfaces of primary colors (Fig. 9) resembling Piet Mondrian's abstract canvas. 

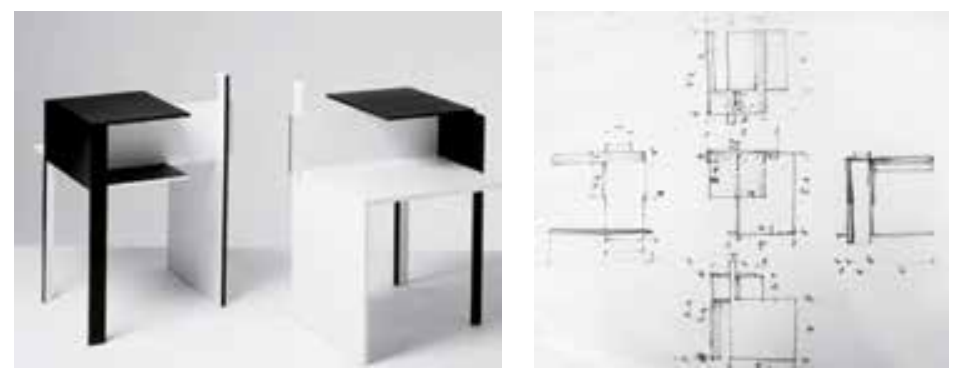

Fig. 10. Gray, Eileen: Mesa De Stijl, 1922-1924. Fig. 11. Gray, Eileen: Dibujo de Mesa De Stijl, 1922-1924. Archive of Art and Design, Victoria \& Albert Museum (ADD/9/197-1980).

eran fluidas y complicadas, después se simplificaron con la introducción de líneas negras ortogonales de diferentes grosores que delimitaban superficies de colores primarios, (Fig. 9) recordando a los lienzos abstractos de Piet Mondrian.

LA MESA DE STIJL. En 1923 Gray diseña una mesa de té (Fig. 10) denominada De Stijl aludiendo directamente al grupo holandés. La definición gráfica del mueble consistía en una planta rodeada de sus cuatro alzados abatidos. (Fig.11) Este sistema de representación le permitiría definir con la misma exactitud muebles y arquitectura de manera que su materialización fuera precisa; para ella ambos campos presentaban similitudes en su concepción, diferenciados solo por una cuestión de escala.

Los conceptos espaciales y compositivos de aquella mesa tenían su antecedente en las ideas de De Stijl sintetizadas en la Red Blue Chair (Fig. 12) de Rietveld; planos independientes colocados ortogonalmente en el espacio buscando el equilibrio formal y la simplicidad estructural. Sin embargo, la referencia más directa a la Mesa De Stijl aparece en la pieza Berlin Chair de la instalación Greater Berlin Exhibition de 1923, realizada por Rietveld y Vilmos Huszár. (Fig. 13) En ella los elementos - patas, brazo, respaldo y asiento- desaparecían en favor de un sistema espacial de planos asimétricos, (18) logrando conquistar el equilibrio y la adecuada estabilidad.

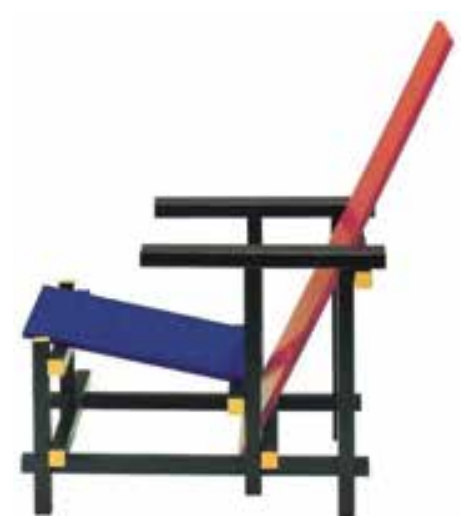

THe DE StiJl TABLE. In 1923, Gray designed a tea (Fig. 10) table called the De Stijl, alluding directly to the Dutch group. The graphical definition of the piece of furniture consisted of a plan surrounded by its four elevations. (Fig. 11) This system of representation would allow Grey to define furniture and architecture with the same accuracy so that the making of it was accurate; for her, both practices were similar in their conception, differentiated only by a question of scale.

The forerunner of the spatial and compositional concepts of the table were De Stijl ideas as demonstrated in the Red Blue Chair (Fig. 12) by G.Rietveld; simple surfaces placed orthogonally in space looking for formal balance and structural simplicity. Nevertheless, the most direct reference to the De Stijl table can be seen in the piece Berlin Chair in the showpiece by G. Rietveld and V. Huszár (Fig. 13) in the Greater Berlin Exhibition of 1923 where the parts such as the legs, arm, support and seat disappeared to make way for a spatial system of asymmetric planes, (18) managing to overcome the problem of balance while achieving adequate stability.

Eileen Gray's De Stijl Table and the Berlin Chair by Gerrit Rietveld show obvious similarities in the asymmetrical spatial equilibrium or the identical color combination, ebony and sycamore wood. Nevertheless, when analyzing the real make up of both pieces of furniture there is a key difference as regards the independence of the surfaces; while in Rietveld's chair each element preserved its formal integrity and every surface was independent, in De Stijl Table, Eileen Gray designed the surfaces running into one another and some can be folded in order to achieve balance. The influence of the chair on the table is obvious but Gray's design is the result of the reworking of what she observed, thus creating an original object. 
La Mesa De Stijl de Gray y la Berlin Chair de Rietveld presentan evidentes similitudes en el equilibrio espacial asimétrico o la combinación cromática idéntica, madera de ébano y de sicomoro. Sin embargo, analizada la verdadera conformación de ambos muebles existe una diferencia clave referida a la independencia de los planos; mientras que en la silla de Rietveld cada elemento conservaba su integridad formal y cada superficie era autónoma, en la mesa, Gray articulaba los planos en continuidad, algunas de sus superficies se plegaban buscando el equilibrio estable en la tridimensionalidad del espacio. La influencia de la silla sobre la mesa es evidente pero el diseño de Gray es fruto de una reelaboración de lo observado consiguiendo así un objeto original.

\section{De Stijl en la arquitectura de Eileen Gray}

SINERgIAs. Los principios de la arquitectura neoplástica enunciados por Theo van Doesburg en 1925 abogaban por la economía y la funcionalidad práctica, invitando al uso de la luz, los materiales y el tiempo como elementos generadores del espacio.

Las técnicas previas al hecho de proyectar aportaron a la arquitectura de Eileen Gray aspectos formales reflejados en coincidencias compositivas entre muebles y objetos, algunos de ellos fundamentados en los principios de De Stijl. Así por ejemplo, el balcón del alzado oeste (Fig. 14) de la E.1027: Maison en bord de mer (1926-1929) conformado por planos horizontales -suelo y techo- independientes del volumen de la casa, evocaba las superficies de los muebles del grupo holandés o de su propio diseño de la mesa De Stijl. La marquesina de la terraza de su segunda vivienda, Tempe à pailla (1932-1934) (Fig. 15) simulaba una homotecia del perfil de la misma mesa, cuyo plano vertical apoyado en los muros pre-existentes se plegaba ortogonalmente, conformando un espacio semiabierto de transición entre el exterior y el interior. El giro de noventa grados del mismo elemento permitía al muro ser al tiempo fachada y cubierta de parte de la terraza, colaborando con su sombra arrojada a la creación de una habitación mediterránea al exterior, un auténtico umbral. Ambos ejemplos demuestran la

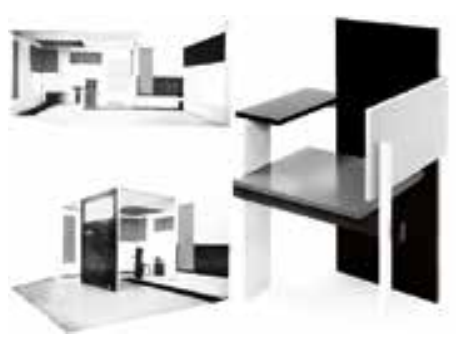

Fig. 13. Rietveld, Gerrity; Huszár, Vilmos: Berlin Chair. Exposición de Arte de Berlín, Juryfreie Kunsthau, 1923.

\section{De Stijl in Eileen Gray's architecture.}

SYNERGIES. Neoplastic architecture's principles declared as such by Theo van Doesburg in 1925, were concerned with the economic aspect and functionality where the use of light, materials and time were encouraged as generators of elements in space.

Techniques used before exhibiting led to compositional coincidences between pieces of furniture and objects (some of them based on De Stijl's principles) in Eileen Gray's architecture. For example, the balcony of the West Elevation (Fig. 14) of the E.1027: Maison en bord de Mer (1926-1929) made up of horizontal surfaces -floor and ceiling- irrelevant of the size of the house, would remind one of the composition of the furniture of the Dutch Group and her own De Stijl Table. And the terrace canopy of her second home, Tempe à Pailla (1932-1934), (Fig. 15) seemed to be a homothetic transformation of the same table, whose vertical surface supported in the pre-existing walls was folded orthogonally forming a semi-open space of transition between the outside and the inside. The rotation of 90 degrees of the same allowed the wall to be both, a facade and a cover for part of the terrace, whereby the shade provided allowed for the creation of an outdoor Mediterranean room, an authentic threshold. Both examples demonstrate the furniture-architecture synergy and how the investigation carried out before designing helped in what was eventually built. 
sinergia mueble-arquitectura y la contribución que las investigaciones previas en torno al diseño objetual aportaban a lo construido.

EL CROMATISMO Y LA REPRESENTACIÓN GRÁFICO-ARQUITECTÓNICA. La representación de la arquitectura de Eileen Gray se caracterizó por plantas de estancias detalladas con sus cuatro alzados-sección abatidos a cada lado. Ese sistema gráfico le facilitó la descripción completa del equipamiento y mobiliario incorporado al espacio en sus ubicaciones precisas. Eileen Gray dibuja su arquitectura adjetivada siempre por el amueblamiento tanto en la vivienda Maison en bord de mer como en la posterior Tempe à pailla (1932-1934).

En el número de L'Architecture Vivante del año 1929, Eileen Gray y Jean Badovici publicaron la casa Maison en bord de mer, adjuntando en el anexo de la revista, un plano a color con la planta del dormitorio y el baño principal (19) con sus cuatro secciones abatidas. La gama cromática utilizada, similar a la de los arquitectos del grupo De Stijl, le permitía cualificar superficies como el suelo, la cama, las paredes, las ventanas y ciertos muebles. Aquella representación gráfica coloreada recordaba en composición y cromatismo al proyecto Hôtel Particulier mostrado por van Doesburg, van Eesteren y Rietveld en la exposición Les Architectes du groupe De Stijl, donde una perspectiva volumétrica en el centro se descomponía en alzados de colores lisos, abatidos en los cuatro laterales. (Fig. 16)
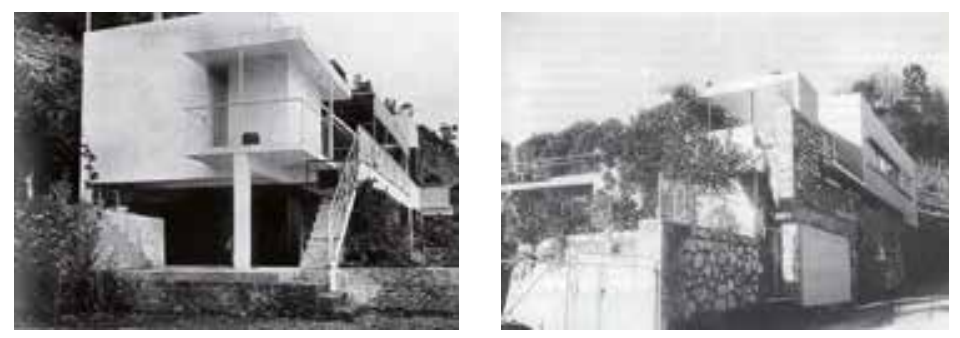

Fig. 14. Gray, Eileen; Badovici, Jean: E.1027: Maison en bord de mer, Roquebrune, Cap-Martin, 1926-1929.

Fig. 15. Gray, Eileen: Tempe à pailla, Castellar, 1932-1934.

system provided the complete description of the equipment and furniture in the space in their exact locations. Eileen Gray always drew her architecture with furnishing in both houses E.1027: Maison en bord de Mer and in the subsequent Tempe à Pailla (1932-1934).

In the edition of L'Architecture Vivante in 1929, Eileen Gray and Jean Badovici published the house E.1027: Maison en bord de Mer, and included a color plan of the bedroom and the main bathroom (19) with its four elevations-sections on each side in the annex of the magazine. The range of colors used, similar to the architects of the De Stijl group, allowed them to specify areas such as the floor, the bed, walls, windows and some of the furniture. This graphical sample, as regards its composition and color brought to mind the project Hôtel Particulier as displayed by Theo van Doesburg, C.van Eesteren and G.Rietveld in the exhibition Les architectes $d u$ Groupe De Stijl, where a volumetric perspective in the middle was broken up into plain colored elevations on the four sides. (Fig. 16)

The postulate number XIV of the principles of neoplastic architecture, as drafted out by Theo van Doesburg advised that "Color is one of the basic means of making harmony visible in architectural relationships". (20) With this in mind, Eileen Gray and Jean Badovici introduced chromatism in the publication of E.1027: Maison in bord de Mer, revealing, with colored photographs of the interior of the house, the result color had on the different rooms of the house, (Fig. 17) which was reminiscent of certain projects by the De Stijl group, such as the Maison Bart de Ligt (Fig. 18) of 1919, or the Cabaret, Cine and Cafe Aubette in Strasbourg, 1926, both by Theo 

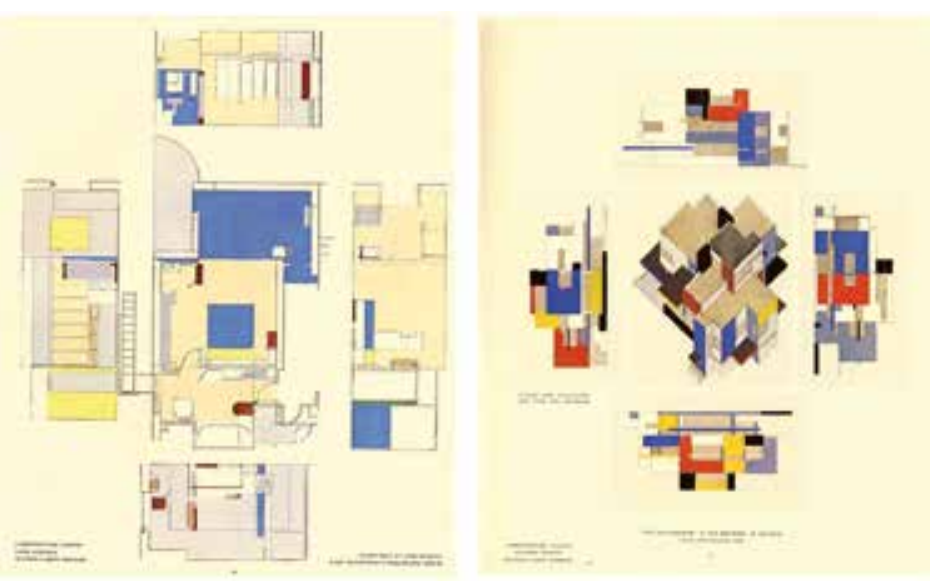

El enunciado número xIV de los principios de la arquitectura neoplástica redactado por Theo van Doesburg advertía: "El color es uno de los medios elementales de hacer visible la armonía de las relaciones arquitectónicas". (20) Siguiendo este razonamiento, Eileen Gray y Jean Badovici introdujeron el cromatismo en la publicación de Maison en bord de mer, desvelando, con fotografías coloreadas del interior el efecto provocado por el color en los espacios (Fig. 17). Dichas ilustraciones recordaban a las de ciertos proyectos de los miembros del grupo De Stijl, como el interior de Maison Bart de Ligt, (Fig. 18) de 1919 o el Cabaret, Cine y Café Aubette en Estrasburgo, de 1926, ambos de Theo van Doesburg. En todos ellos se subrayaba la importancia del cromatismo a través de la descomposición de los planos -suelos y techos- creando una percepción espacial novedosa, ajena a las verdaderas dimensiones y geometría del volumen interior.

LA DISOLUCIÓN DE LOS LÍMITES DEL ESPACIO. El enunciado numero XII redactado por Theo van Doesburg referente a la arquitectura plástica exponía que: "La nueva arquitectura es anti-cúbica, es decir, los diferentes espacios no
Fig. 16. [Izquierda] Gray, Eileen; Badovici, Jean: plano de dormitorio principal y baño de E.1027: Maison en bord de mer. Publicado en LArchitecture Vivante, otoño-invierno de 1929. [Derecha] Van Doesburg, Theo; van Eesteren, Cornelis: Axonometría y alzados de Hôtel Particulier, 1920.

van Doesburg. In all of these projects, the importance of chromatics could be seen by the breaking down of the plans, floors and ceilings, thus creating a new perception of space, far from the real dimensions and geometry of the interior volume.

THE DISSOLUTION OF THE LIMITS OF SPACE. The postulate number XII drafted by Theo van Doesburg regarding plastic architecture informed that: "New architecture is anti-cubical, that is, the different rooms are not compressed in a closed cube; quite the opposite, the different cellular rooms are developed eccentrically, from the center towards the outside of the cube, therefore the dimensions of height, width and depth receive a new plastic expression. Thus the modern house will give the impression of being projected, suspended in the air, contrary to the law of gravity". (21)

This principle recalls aspects of the impact of De Stijl movement on Eileen Gray's architecture and explains the innovative concept of the implementation of the ground floor plan of one of her first projects: the Maison pour un Ingénieur. (Fig.19) In this example, the architect investigates and freely reinterprets her knowledge of both, the principles of De Stijl as well as the five points of architecture as established by Le Corbusier.

Maison pour un Ingénieur (1931) presents an antithesis in the configuration of its two floors: the ground floor plan is open to its immediate environment and the first floor plan is concentrated in a closed area with a perimeter movement and a layout aided by studied flexible furniture. On the whole the project responded to the neoplastic postulate number 
se comprimen en un cubo cerrado. Al contrario, las diferentes células espaciales se desarrollan excéntricamente, del centro hacia la periferia del cubo; por lo tanto, las dimensiones de alto, ancho y profundidad reciben una nueva expresión plástica. Así la casa moderna dará la impresión de estar proyectada, suspendida en el aire, contrariamente a la ley de la gravedad". (21)

Este principio rememora aspectos del impacto del movimiento De Stijl en la arquitectura de Eileen Gray y explica la novedosa concepción de la implantación en el terreno de la planta baja de uno de sus primeros proyectos: la Maison pour un ingénieur. (Fig. 19) En aquel ejemplo, la arquitecta investiga y reinterpreta con libertad su conocimiento, tanto de los principios del De Stijl como de los cinco puntos de la arquitectura enunciados por Le Corbusier.

Maison pour un ingénieur (1931) presenta una antítesis en la configuración de sus dos plantas: la planta de acceso, abierta a su entorno in-
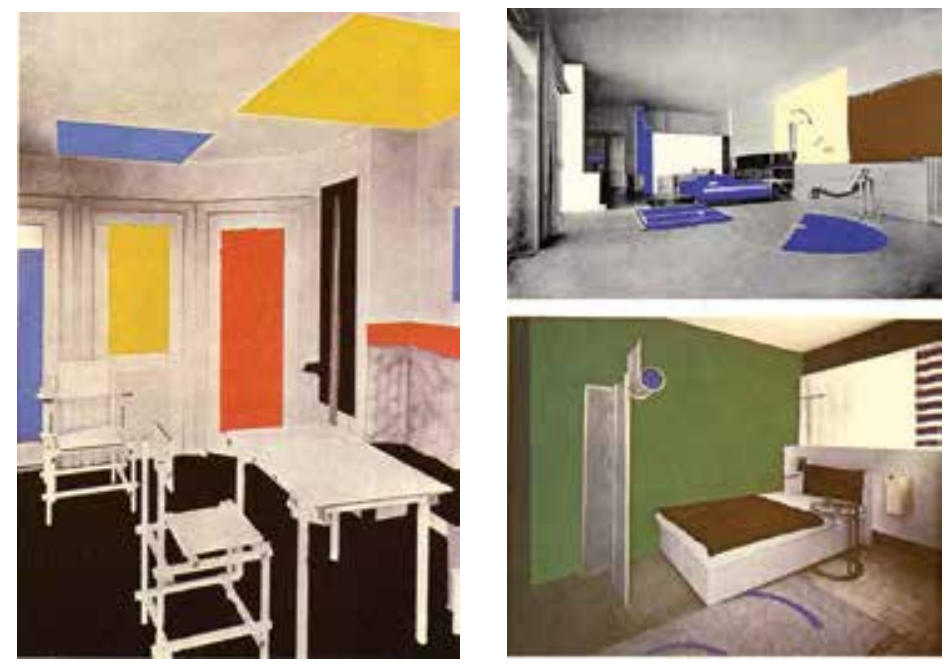

Fig. 17. Gray, Eileen; Badovici, Jean: E.1027: Maison en bord de mer, 1926-1929. Fotografía coloreadas de interiores publicadas en L'Architecture Vivante, otoño-invierno de 1929. Fig. 18. Van Doesburg, Theo; Rietveld, Gerrit: Interior de Maison Bart de Ligt, 1919. Fotografía publicada en De Stijl, III n. 12, noviembre 1920. Fig. 19. Gray, Eileen: Maison pour un ingénieur, 1926.

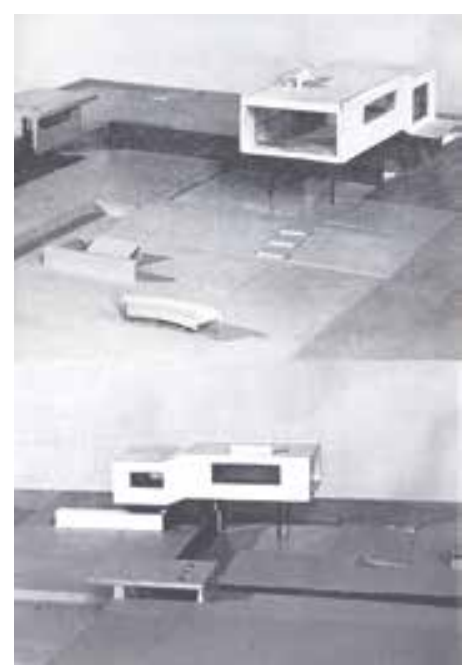

XII; a house suspended in the air, defying gravity, with a structural system of four sets of pilotis that were set back from the upper part of the building structure, thus lending an air of lightness to the overall structure.

While the first floor plan was a parallelepiped with two different slab levels, illuminated by horizontal windows and with any movement being concentrated on the outer part, the ground floor plan, however, was a direct attempt at the architectural concepts set out in the De Stijl movement, mainly when it came to the fluidity of the space available and how this was used. (Fig.20) The use of walls, which do not go right up to the ceiling, but rather expanding outwardly, created an open floor where the interior rules of composition were carried through and multiplied to the outside, thus differentiating enclosed spaces by inclines. The existence of two different levels of the slab of the first floor achieved areas of different free heights on the ground floor, which got higher thanks to the fact that the level of the ground was also modified and changed. As a result, there was a variety of sizes of spaces and areas under the upper part of the house in each one of the flanks of the house.

The eccentric development of the composition of the ground floor plan of Maison pour un Ingénieur (Fig. 21) resembles that of the Maison Rosenberg of Theo van Doesburg and C.van Eesteren displayed in the famous exhibition by the De Stijl group (Fig. 22) and also to Mies van der Rohe's brick houses where space was flowing on having been treated as matter and forgetting the static character, creating blurred lines in the limits between the exterior and the interior. 
mediato y la planta primera, concentrada en un volumen cerrado con una circulación perimetral y una disposición del programa doméstico, ayudada por un estudiado mobiliario flexible. En conjunto, el proyecto respondía al enunciado neoplástico número XII; una casa suspendida en el aire desafiando a la gravedad, con un sistema estructural de cuatro pares de pilotis retranqueados del volumen superior que conseguían aportar ligereza al conjunto.

Si la planta superior era un paralelepípedo con dos niveles diferentes de forjado, iluminada por ventanas horizontales en sus alzados largos y con una circulación interior concentrada en la periferia, la planta baja, sin embargo, constituía un ensayo directo de los conceptos aportados por el movimiento De Stijl a la arquitectura, principalmente el de la fluidez del espacio y el tratamiento de éste como materia. (Fig. 20) La disposición de muros que no rozan el techo expandiéndose hacia la periferia conformaba una planta abierta, donde las reglas compositivas internas se multiplicaban al exterior diferenciando espacios acotados por desniveles. La existencia de dos cotas diferentes del forjado de la planta primera conseguía establecer espacios de alturas libres diversas en la planta baja, que se incrementaban al haber manipulado también los niveles del terreno. De esta manera, el espacio bajo el volumen superior presentaba una variedad de niveles de compresión espacial en cada uno de los flancos de la casa.

El desarrollo excéntrico de la composición de la planta baja de Maison pour un ingénieur (Fig. 21) recuerda al de la Maison Rosenberg de Theo van Doesburg y C. van Eesteren, expuesto en la famosa exposición del grupo De Stijl (Fig. 22) y también a la de la casa de ladrillo de Mies van der Rohe, cuyo espacio fluía al ser tratado como materia olvidando el carácter estático y difuminando los límites entre el exterior y el interior.

Conclusión. En definitiva, la auto-referencia entre muebles, pinturas, tapices y arquitectura de ciertos miembros de De Stijl con la producción de Eileen Gray demuestra la sinergia establecida entre la obra de la arquitecta
Fig. 20. Perspectiva axonométrica de Maison pour un ingénieur. Dibujo de la autora.
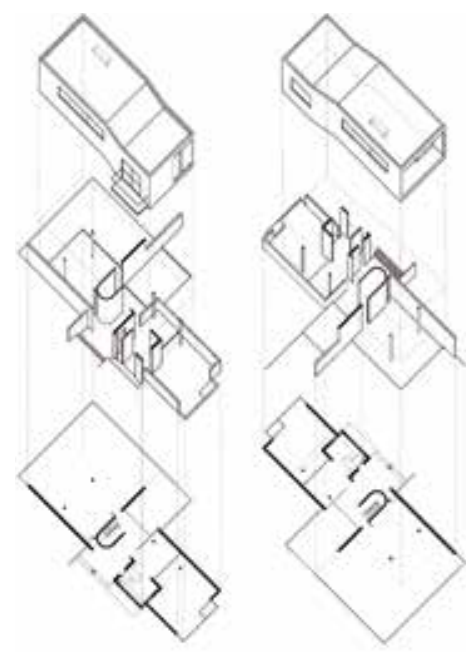

Conclusion. To sum up, the self-reference between furniture, paintings, tapestries and architecture of certain members of De Stijl movement and Eileen Gray's work demonstrates the synergy established with the work of this female architect as well as an architectural spectrum which leads us to believe that the movement in question may well have had more of an influence on the author's work than the men who were supposedly responsible for her designs and end products, so influential at the time, such as Jean Badovici who was her mentor and Le Corbusier, a competitive reference. Both, the artistic and architectural ideas of the Dutch group played a part in Gray's formative stage, influencing her experiential learning, just like Adolf Loos or as demonstrated in other investigations of social constructivist architecture.

The two-way relationship between furniture design and architecture, whether in theory or having been built, has been studied in depth, and as a result, this article has tried to make a point of the ideological and artistic intervention of other factors or influences such as the De Stijl group, whose postulates allowed Eileen Gray to stand out, and from a critical point of view, redo what she had observed, turning her creations into her own originals, unlike work done by other members of what was known to be the official modernity of the time. 
y un espectro arquitectónico alejado de los protagonistas masculinos que han centrado casi siempre los discursos académicos referidos a la autora: Jean Badovici como mentor y Le Corbusier como referente competitivo. Las ideas del grupo holandés concurrieron en el debate, tanto artístico como arquitectónico, en la etapa de formación de la arquitecta, contaminando su aprendizaje experimental, exactamente igual que lo hicieron Adolf Loos o ciertas investigaciones de la arquitectura social constructivista.

La relación bidireccional entre el diseño de muebles y su arquitectura -teórica o construida- ha sido estudiada con profusión, por ello en este artículo se ha tratado de subrayar la intervención ideológica y artística de terceros actores como el grupo De Stijl, cuyos postulados permitieron a Eileen Gray singularizarse al reelaborar de manera crítica lo observado, convirtiendo sus creaciones en originales respecto a las del resto de protagonistas de la modernidad oficial.

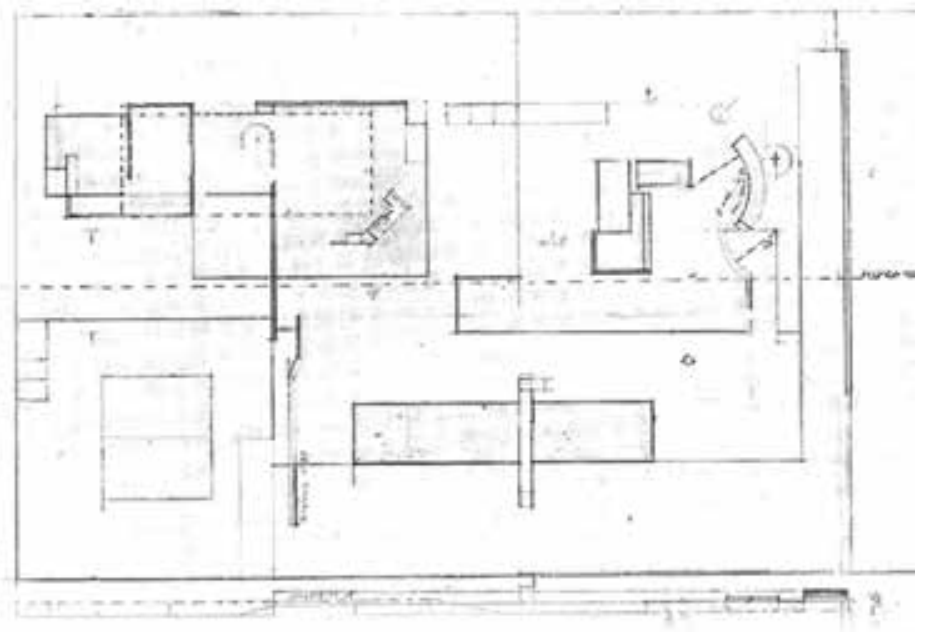

Fig. 21. Gray, Eileen: Planta baja y parcela de la Maison pour un Ingénieur. Archive of Art and Design, Victoria \& Albert Museum (ADD/9/211/1-1980).

Fig. 22. Van Doesburg, Theo; van Eesteren, Cornelis: Planta baja y parcela de la Maison Rosenberg, 1923.

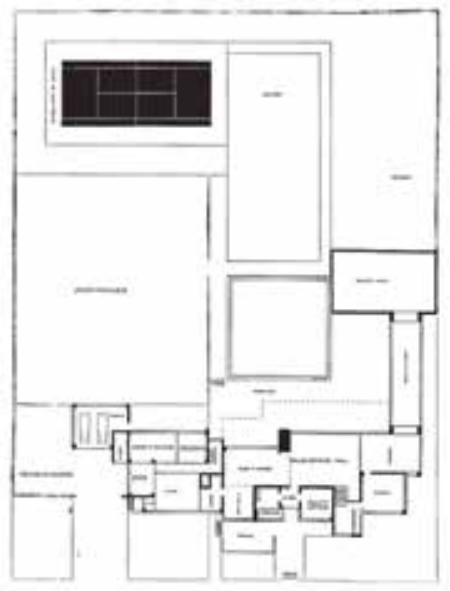

\section{REFERENCIAS}

ADAM, Peter. Eileen Gray: Architect/Designer. Nueva York: Harry N. Abrams, Inc Publishers, 1987.

ADAM, Peter. Eileen Gray. Her life and Work. Londres: Ed. Thames \& Hudson, 2009.

CASTRO NOGUEIRA, L. La risa del Espacio. Madrid: Ed. Tecnos, 1997. CONSTANT, Caroline. Eileen Gray. Londres: Ed. Phaidon, Press Limited, 2000.

CREGO CASTAÑO, Charo. El espejo del orden. EL arte y la estética del grupo holandés De Stijl. Madrid: Ed. Akal, 1997.

GARNER, Philippe. Eileen Gray; Design and Architecture, 1878-1976. Köln:Taschen Gmbh, 2006.

LOYE, Brigitte. Eileen Gray, 1879-1976: Architecture Design. París: Ed. Analeph/J.P.Viguier, 1984.

MONDRIAN, Piet. 'L'Architecture Future Néo-Plasticienne' en L'Architecture Vivante, otoño-invierno, 1925.

VAN DOESBURG, Theo. 'L'Evolution de la Architecture Moderne en Hollande' en L'Architecture Vivante, Otoño-Invierno,1925.

ZEVI, Bruno. Poética de la arquitectura neoplástica. Buenos Aires: Ed. Víctor Lerú S.R.L, 1960. (Edición original: Poetica dellarchitettura neoplastica. Milán: Ed. Tamburini, 1953).

\section{REFERENCES}

ADAM, Peter. Eileen Gray: Architect/Designer. New York: Harry N. Abrams, Inc Publishers, 1987.

ADAM, Peter. Eileen Gray. Her life and Work. London: Ed. Thames \& Hudson, 2009.

CASTRO NOGUEIRA, L. La risa del Espacio. Madrid: Ed. Tecnos, 1997. CONSTANT, Caroline. Eileen Gray. London: Ed. Phaidon, Press

Limited, 2000.

CREGO CASTAÑO, Charo. El espejo del orden. EL arte y la estética del grupo holandés De Stijl. Madrid: Ed. Akal, 1997.

GARNER, Philippe. Eileen Gray; Design and Architecture, 1878-1976. Köln:Taschen Gmbh, 2006.

LOYE, Brigitte. Eileen Gray, 1879-1976: Architecture Design. Paris: Ed. Analeph/J.P.Viguier, 1984.

MONDRIAN, Piet. 'LAArchitecture Future Néo-Plasticienne' in L'Architecture Vivante, Autum-Winter, 1925.

VAN DOESBURG, Theo. 'L'Evolution de la Architecture Moderne en Hollande', in: L'Architecture Vivante, Autum-Winter,1925.

ZEVI, Bruno. Poética de la arquitectura neoplástica. Buenos Aires: Ed. Víctor Lerú S.R.L, 1960. (Original Edition: Poetica dell'architettura neoplastica. Milano: Ed. Tamburini, 1953). 


\section{NOTAS}

1. CASTRO NOGUEIRA, L. La risa del Espacio. Madrid: Ed. Tecnos, 1997. pp. 29-41.

2. LOYE, Brigitte. Eileen Gray, 1879-1976: Architecture Design. París: Ed. Analeph/J.P.Viguier, 1984. pp. 17-18. En su galería Jean Desert, Eileen Gray expuso sus obras junto a la de amigos artistas como Seizo Sugawara, Ossip Zadkine, Chana Orloff y Evelyn Wild.

3. Carta remitida por Jan Wils a Eileen Gray el 9 de diciembre de 1922, indicando las modificaciones realizadas en la colocación de las piezas en el stand de Amsterdam. Archive of Art and Design, Victoria \& Albert Museum, (ADD9/162-1980).

4. Originalmente la instalación se denominó Hall 1922, cambiando el título a Chambre à coucher. Boudoir Monte-Carlo. Las imágenes de la exposición fueron reproducidas en L'Architecture Vivante, en 1924 y en Intérieurs Français, en 1925.

5. CONSTANT, Caroline. Eileen Gray. Londres: Ed. Phaidon, Press Limited, 2000. p. 52. "[...]It is the room of the daughter of Doctor Caligari in all its horror". Recorte de prensa Le Salon des Décorateurs, 5 mayo de 1923. Archive of Art and Design Victoria \& Albert (ADD9/13-1980). 6. CONSTANT, C. Opus cit. p. 54. "I am highly interested in it and should like to see more of your work. Could you perhaps send me a number of a revue containing your works?[...] Do you have any modern movement in your country ?[...]" Postal remitida por J.J.P. Oud a Eileen Gray, 31 agosto 1924. Archive of Art and Design, Victoria \& Albert Museum (ADD/9/163-1980).

7. La revista Wendingen era el órgano de divulgación de la Escuela de Amsterdam. Su período de publicación comprende de 1918 a 1926 . Su subtítulo era Periódico mensual para decoración y construcción de la arquitectura y la Amiticia. La Sociedad Arquitectura y Amistad estaba dominada por tendencias masónicas e influencias de la teosofía y de la mística. Sus portadas constituyen una excepcional contribución a la historia del grafismo y la tipografía moderna

8. Jean Badovici (1893-1956) era un arquitecto rumano formado en París, cuya actividad estuvo centrada en la crítica arquitectónica. Fue director de la revista L'Architecture Vivante - 1923 y1933- y su relación personal con Eileen Gray impulsó y orientó la trayectoria de la diseñadora hacia el proyecto arquitectónico.

9. VAN DOESBURG, T. en ZEVI, B, 1960, p. 50.

10. El movimiento De Stijl se funda en 1917 en la Universidad Holandesa de Leiden por Theo van Doesburg y Piet Mondrian, uniéndose pintores como Vilmos Huszár y Bart van der Leck, escultores como G. Vantongerloo y arquitectos como Robert van't Hoff, Jan Wils, Bernard Bijvoet, J.J.P. Oud y Cornelis van Eesteren. En 1918, el primer manifiesto del grupo reivindica una plástica elemental y espiritual capaz de suprimir cualquier forma natural contraria a la expresión del arte. La idea de estilo como no estilo impulsaba la investigación de un método general. En 1925 sus ideas fueron especificadas en diecisiete principios fundamentales relativos a la arquitectura del grupo. 11. ZEVI, Bruno. Poética de la arquitectura neoplástica. Buenos Aires: Ed. Víctor Lerú S.R.L, 1960. (Original: Poetica dell'architettura neoplastica, Ed Tamburini, Milano, 1953). p. 49.

12. “[...]van Eesteren anotó en su diario que a la inauguración asistieron entre otros, Mallet-Stevens, Lurcat, Guévrékian y Le Corbusier, cuyo aspecto mal afeitado y las ropas de trabajo que vestía rebelaban una ansiosa precipitación". Theo van Doesburg afirma de Mallet-Stevens y de Le Corbusier que "no sólo habían visitado la exposición de De Stijl, sino que habían tomado apuntes de ella". VAN DOESBURG, Theo, Data en Feiten, De Stijl, vII, 79/84 1927 p. 56 visto en CREGO CASTAÑO, Charo. El espejo del orden. EL arte y la estética del grupo holandés De Stijl. Madrid: Ed.

Akal, 1997.p. 95.

13. Se expusieron los proyectos Joyería, de G. Rietvelt, en Amsterdam (1922); Fábrica Purmered, de J.J.P. Oud o la Residencia en La Hague, de Jan Wils. El único arquitecto no holandés incluido en la muestra fue Mies van der Rohe, exponiendo Casa de campo de Hormigón y Casa de campo de Ladrillo.

14. ADAM, Peter. Eileen Gray. Her life and Work. Londres: Ed. Thames \& Hudson, 2009. pp.72-73.

15. MONDRIAN, Piet. 'LAArchitecture Future Néo-Plasticienne', en:

LArchitecture Vivante, Otoño-Invierno, 1925. pp 11-13.

16. VAN DOESBURG, Theo. 'L'Evolution de la Architecture Moderne en Hollande' en L'Architecture Vivante, Otoño-Invierno,1925. pp.14-20.

17. ADAM, Peter. Eileen Gray. Her life and Work. Londres: Ed. Thames \& Hudson, 2009. p.73.

18. G.Rietvelt sintetizó los fundamentos arquitectónicos de De Stijl en la Maison Schröder de Utrech (1924) con mecanismos como la asimetría de planos, los colores primarios y una distribución interior flexible. Eileen Gray y Jean Badovici visitaron aquella casa in situ, para su posterior publicación en L'Architecture Vivante.

19. L'Architecture Vivante, 1929.

20. VAN DOESBURG, Theo. 'L'Evolution de la Architecture Moderne en Hollande' en L'Architecture Vivante, Otoño-Invierno,1925. pp.19-20. 21. Ibidem.

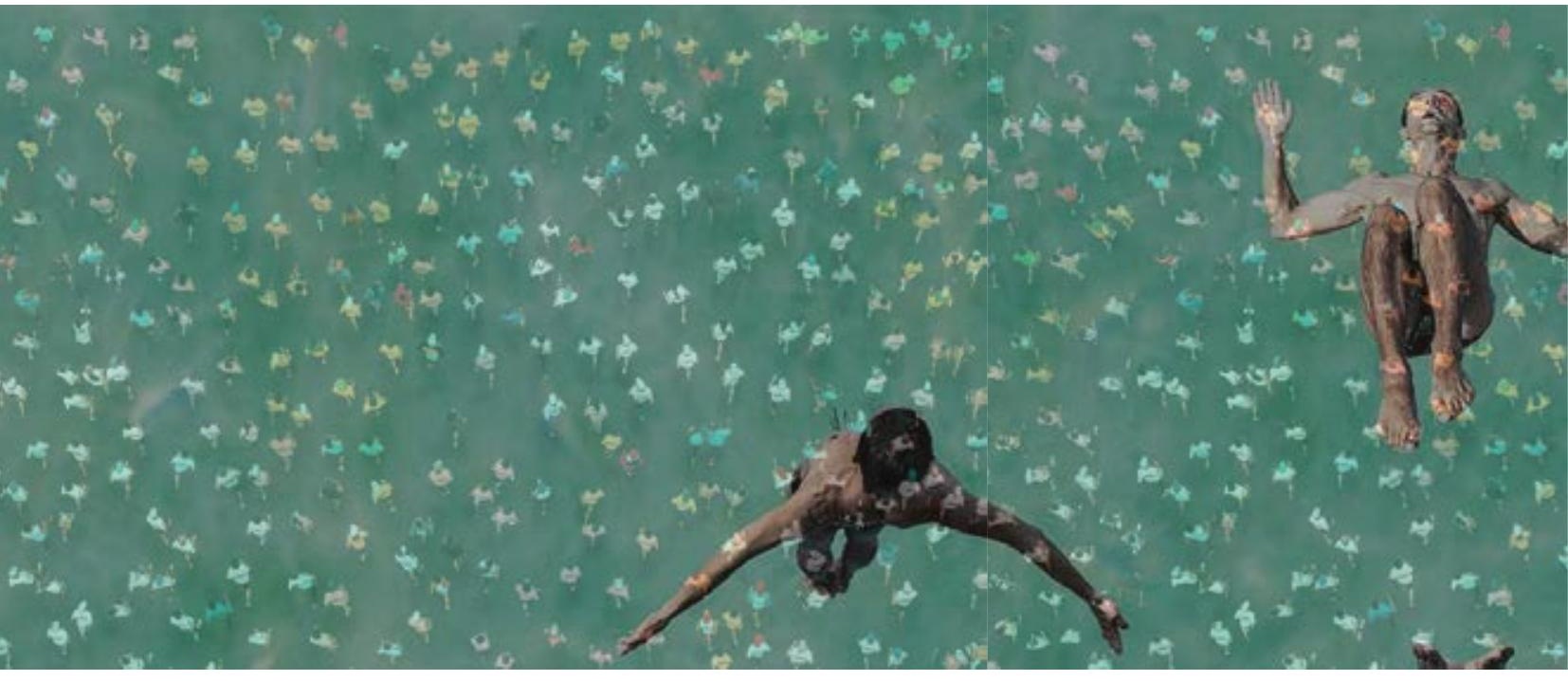




\section{NOTES}

1. CASTRO NOGUEIRA, L. La risa del Espacio. Madrid: Ed. Tecnos, 1997. pp. 29-41.

2. LOYE, Brigitte. Eileen Gray, 1879-1976: Architecture Design. Paris: Ed. Analeph/J.P.Viguier, 1984. pp. 17-18. In her gallery, Eileen Gray put her work on show together with that of other artist friends like Seizo Sugawara, Ossip Zadkine, Chana Orloff and Evelyn Wild.

3. Letter sent by Jan Wils to Eileen Gray in December of 1922, indicating the modifications carried out in the placement of the pieces in the stand in Amsterdam. Archive of Art and Design, Victoria \& Albert Museum, (ADD9/162-1980).

4. Originally the project was called Hall 1922, changing the title to Chambre à coucher. Boudoir Monte-Carlo. The images of the exhibition were published in L'Architecture Vivante in 1924, and in Intérieurs Français in 1925.

5. CONSTANT, Caroline. Eileen Gray. London: Ed. Phaidon, Press Limited, 2000. p. 52. "[...]It is the room of the daughter of Doctor Caligari in all its horror”. Press clipping Le Salon des Décorateurs, May 5th, 1923. Archive of Art and Design Victoria \& Albert (ADD9/13-1980).

6. CONSTANT, Caroline. Eileen Gray. London: Ed. Phaidon, Press Limited, 2000. p. 54. "I am highly interested in it and should like to see more of your Work. Could you perhaps send me a number of a revue containing your works?[...]Do you have any modern movement in your country ?[...]" Postcard sent by J.J.P.Oud to Eileen Gray, August, 31st, 1924. Archive of Art and Design, Victoria \& Albert Museum (ADD/9/163-1980).

7. Wendingen magazine was the media used for spreading information about the School of Amsterdam. Its period of publication covered from 1918 to 1926. Its subtitle was Monthly Newspaper for the Decoration and Construction of Architecture and the Amiticia. The Company Architecture and Friendship was dominated by Masonic trends and influences of teosophy and of mysticism. Its front pages were an exceptional contribution to the history of graphic design and the modern typography.

8. Jean Badovici (1893-1956) was a Rumanian architect trained in Paris whose principal activity was that of architectural critique. He was the director of the magazine L'Architecture Vivante - 1923 y1933-, and his personal relationship with Eileen Gray stimulated and orientated the path of the designer towards the architectural project.

9.VAN DOESBURG, T. en ZEVI, B, 1960, p.50.

10. The De Stijl movement was founded in 1917 in the Dutch University of Leiden by Theo van Doesburg and Piet Mondrian, bringing together painters like Vilmos Huszár and Bart van der Leck, sculptors like G.Vantongerloo and architects such as Robert van't Hoff, Jan Wils, Bernard Bijvoet, J.J.P.Oud and Cornelis van Eesteren. In 1918, the first manifest of the group claims an elementary and spiritual plastic art capable of suppressing any natural form opposed to the expression of art. The idea of style as non style stimulated the investigation of a general method. En 1925, their ideas were specified in seventeen fundamental postulates relative to the architecture of the group. 11. ZEVI, Bruno. Poética de la arquitectura neoplástica. Buenos Aires: Ed. Víctor Lerú S.R.L, 1960. (Original: Poetica dell'architettura neoplastica, Ed Tamburini, Milano, 1953). p.49.

12. "[...] van Eesteren annotated in his diary that at the inauguration Mallet-Stevens, Lurcat, Guévrékian and Le Corbusier were present, among others, and these badly shaved people, who turned up in work clothes did so as if they were rebelling against an anxious fall[...]". Theo van Doesburg affirms of Mallet-Stevens and of Le Corbusier that: "not only they had visited the exhibition of De Stijl, but they had taken notes there". VAN DOESBURG, Theo, Data en Feiten, De Stijl, viI, 79/84 1927 p. 56 seen at CREGO CASTAÑO, Charo. El espejo del orden. EL arte y la estética del grupo holandés De Stijl. Madrid: Ed. Akal, 1997. p.95.

13. The projects were put on display: G.Rietvelt's Jeweler's shop in Amsterdam (1922), Factory Purmered de J.J.P.Oud or the Residence in Jan Wils's Hague. The only non Dutch architect included in the exhibition was Mies van der Rohe with Brick Country House and Concrete Country House.

14. ADAM, Peter. Eileen Gray. Her life and Work. London: Ed. Thames \& Hudson, 2009. pp.72-73.

15. MONDRIAN, Piet. 'LArchitecture Future Néo-Plasticienne', in: L'Architecture Vivante, Autum-Winter, 1925. pp 11-13.

16. DOESBURG, Theo van. 1925 pp.14-20.

17. ADAM, P, 2009, p.73.

18. G.Rietvelt synthesized the architectural foundations of De Stijl in Maison Schröder, (1924) with mechanisms such as the asymmetry of planes, primary colors and an interior flexible distribution. Eileen Gray and Jean Badovici visited the house in situ, for their later publication in L'Architecture Live Through You.

19. L'Architecture Vivante, 1929.

20. VAN DOESBURG, Theo. 'L'Evolution de la Architecture Moderne en Hollande', in: L'Architecture Vivante, Autum-Winter,1925. pp.19-20. 21. Ibidem.

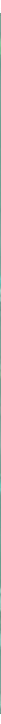

